\title{
Analysis of tryptic digests indicates regions of GvpC that bind to gas vesicles of Anabaena flos-aquae
}

Correspondence

Anthony E. Walsby

a.e.walsby@bristol.ac.uk

Received 9 December 2005

Revised 17 February 2006

Accepted 21 February 2006

\author{
Peter G. Dunton, ${ }^{1}$ William J. Mawby, ${ }^{2}$ Virginia A. Shaw ${ }^{2}$ \\ and Anthony E. Walsby ${ }^{1}$
}
School of Biological Sciences ${ }^{1}$ and Department of Biochemistry ${ }^{2}$, University of Bristol, Bristol BS8 1UG, UK

\begin{abstract}
The gas vesicles of the cyanobacterium Anabaena flos-aquae contain two main proteins:
GvpA, which forms the ribs of the hollow cylindrical shell, and GvpC, which occurs on the outer surface. Analysis by MALDI-TOF MS shows that after incubating Anabaena gas vesicles in trypsin, GvpA was cleaved only at sites near the N-terminus, whereas GvpC was cleaved at most of its potential tryptic sites. Many of the resulting tryptic peptides from GvpC remained attached to the underlying GvpA shell: the pattern of attachment indicated that there are binding sites to GvpA at both ends of the 33-residue repeats (33RRs) in GvpC, although one of the tryptic peptides within the $33 R R$ did not remain attached. Tryptic peptides near the two ends of the GvpC molecule were also lost. The mean critical collapse pressure of Anabaena gas vesicles decreased from $0.63 \mathrm{MPa}$ to $0.20 \mathrm{MPa}$ when GvpC was removed with urea or fully digested with trypsin; partial digestion resulted in partial decrease in critical pressure.
\end{abstract}

\section{INTRODUCTION}

Gas vesicles are the hollow structures that provide buoyancy in bacteria and archaea. The wall of the gas vesicle has two principal components, the gas vesicle proteins GvpA and GvpC. Crystallographic studies of Blaurock and his collaborators provided information on the folding of the main constituent, GvpA, of gas vesicles (Blaurock \& Wober, 1976; Blaurock \& Walsby, 1976) but there is little direct information on the arrangement of the outer protein, GvpC. We describe investigations using trypsin to digest the outer protein component that provide some further information on which parts are bound to the structure.

In cyanobacteria the gas vesicle has the form of a hollow cylinder closed at each end by a hollow conical cap: the cylinder varies in length; the diameter is uniform within species but varies in different species. The wall of the cylinder and caps is $2 \mathrm{~nm}$ thick and is formed by ribs of width $4.6 \mathrm{~nm}$, which in halobacterial gas vesicles (Offner et al., 1998) have been shown to represent turns of a shallow spiral. The gas vesicle is rigid (Walsby, 1982) and highly permeable to gases (Walsby, 1969) but impermeable to liquid water, which is excluded by the hydrophobic nature of the inside surface (Worcester, 1975).

Abbreviations: 33RR, 33-residue repeat; $M_{\mathrm{i}}$, monoisotopic mass; MALDI-TOF, matrix assisted laser desorption ionization-time of flight.
The wall of the gas vesicle is formed entirely of protein (Walsby \& Buckland, 1969; Jones \& Jost, 1970, 1971). The main constituent, GvpA, a small hydrophobic protein that forms the ribs and spans the wall, accounts for about $90 \%$ of the mass. In Anabaena flos-aquae and several other cyanobacteria GvpA is a protein of 70 amino acid residues (Tandeau de Marsac et al., 1985; Hayes et al., 1986). X-ray crystallography shows that GvpA is arranged in two layers of $\beta$-sheet within the thickness of the wall, with two $\beta$-chains in each layer tilted at an angle of about $55^{\circ}$ to the rib axis (Blaurock \& Walsby, 1976; McMaster et al., 1996). A model indicates that this angle is generated by alternate chains of seven and eight dipeptides, which would set the chains at $53 \cdot 8^{\circ}$ to the rib and place the hydrogen bonds between chains at close to the angle that provides the greatest stability, $54 \cdot 7^{\circ}$ to the cylinder axis (Walsby, 1994).

The gene for the second gas-vesicle protein, GvpC, was first found in Calothrix sp., where it encodes a hydrophilic protein of 162 residues. The sequence indicated four repeats of a 33 -residue repeat $(33 R R)$ motif between an 18-residue $\mathrm{N}$ terminal and a 12-residue C-terminal sequence; the nucleotide sequence indicates that the $99 \mathrm{bp}$ repeats encoding the $33 R R$ s have an underlying $33 \mathrm{bp}$ repeat, though there is little discernible homology between the encoded 11RRs in the protein (Damerval et al., 1987). There have been no crystallographic investigations of GvpC but secondary structure predictions suggest that the whole molecule is in the form of a long $\alpha$-helical rod (http://www.predictprotein. org/; Rost et al., 2004). 
In A. flos-aquae, gvpC encodes a larger protein of 193 residues, with five $33 R R$ s between an 18 -residue $\mathrm{N}$-terminal and a 10-residue C-terminal sequence. The encoded protein was shown to be a structural component of gas vesicles by sequencing tryptic digests of the purified structures (Hayes et al., 1988). GvpC can be removed from isolated gas vesicles by rinsing in concentrated urea without the structures collapsing; this demonstrates that it is located on the outer surface (Walsby \& Hayes, 1988). The GvpC rebinds to the surface if the urea is dialysed away, and quantitative measurements indicate a binding ratio of one GvpC to 25 GvpA molecules (Buchholz et al., 1993), or one $33 R R$ to five GvpAs (Kinsman et al., 1995). When GvpC is removed, the gas vesicles become less stable and the ribs more easily separated; the stability recovers completely, however, when GvpC rebinds (Hayes et al., 1992). It has been suggested that GvpC crosses the ribs, binding them together (Buchholz et al., 1993) but there is no independent evidence of this.

It is likely that each of the five $33 R R$ s in the GvpC of A. flosaquae forms an identical interaction with the underlying crystalline array of GvpA molecules. Information on the orientation of the outer protein can be obtained by exposing the gas vesicle surface to compounds that label or digest proteins. Belenky et al. (2004) analysed digested gas vesicles by MALDI-TOF mass spectrometry. They showed that trypsin removed the $\mathrm{N}$-terminal tetrapeptide of sequence AVEK- from GvpA and carboxypeptidase cleaved the last five peptide bonds in -AAVPA from the C-terminal end; these sequences must occur at the outer, water-facing surface of the gas vesicle. Their analyses were performed on gas vesicles rinsed with urea to remove the adhering layer of GvpC. We have analysed isolated gas vesicles retaining the surface layer of GvpC; digestion of these entire gas vesicles has yielded information on which parts of the GvpC molecule are bound to GvpA.

In the unicellular cyanobacterium Microcystis sp. there are 10 different $g v p$ genes in a linear cluster $g v p A, C, N, J, X, K$, $F / L, G, V, W$ (Mlouka et al., 2004; Dunton \& Walsby, 2005). In A. flos-aquae, nine of the same genes are found in the same order, but one, $g v p X$, is absent (see Kinsman \& Hayes, 1997, and GenBank accession no. U17109). Two of the cyanobacterial genes ( $g v p J$ and $g v p K)$ encode proteins that have sections homologous to parts of GvpA and may be structural components of the gas vesicle. We have looked for products of these genes in gas vesicles by MALDI-TOF MS.

In halobacteria there are 14 gvp genes (Horne et al., 1991), including $g v p A$, which also encodes the main structural protein, and a weakly homologous $g v p C$, which also encodes another structural protein (Offner et al., 1996). Eight of the genes are essential for gas vesicle production (Offner et al., 2000 ), including two ( $g v p J$ and $g v p M)$ with parts homologous to gvpA. Shukla \& DasSarma (2004) showed that antibodies raised to products of five other $g v p s$ ( $g v p F, G, J, L$ and $M$ ) bind to isolated gas vesicles.

\section{METHODS}

Cultures of cyanobacteria and isolation of gas vesicles. Cultures of Anabaena flos-aquae CCAP 1403/13f were grown at $20{ }^{\circ} \mathrm{C}$ in low irradiance, $5-15 \mu \mathrm{mol} \mathrm{m} \mathrm{m}^{-2} \mathrm{~s}^{-1}$, in the medium of Booker \& Walsby (1979). The procedures of Walsby \& Bleything (1988) were followed for the isolation of gas vesicles. Cells were lysed by osmotic shrinkage in sucrose and the isolated gas vesicles rinsed by repeated centrifugal flotation, followed by collection and further rinsing on membrane filters of $50 \mathrm{~nm}$ pore size. Throughout these procedures the preparations were suspended in solutions containing $5 \mathrm{mM} \mathrm{NaCN}$, to prevent the growth of bacteria, and $10 \mathrm{mM}$ $\mathrm{K}_{2} \mathrm{HPO}_{4}$, to maintain the $\mathrm{pH}$ at about 8 ; this prevents loss of the $\mathrm{GvpC}$ and the ensuing weakening of the isolated gas vesicles.

Digestion with trypsin and Staphylococcus V8 protease. Aliquots of $100 \mu \mathrm{l}$ of buffered trypsin solution were made up to $6 \mathrm{mg} \mathrm{ml}^{-1}$ in Tris/HCl (Sigma), pH 8. For MALDI-TOF analysis, samples of concentrated gas vesicles were pipetted into the buffered trypsin and incubated for between 1 and $24 \mathrm{~h}$ at $37^{\circ} \mathrm{C}$. The gas vesicles were then rinsed three times by centrifugal flotation through buffer containing $5 \mathrm{mM} \mathrm{NaCN}$ and $10 \mathrm{mM} \mathrm{K}_{2} \mathrm{HPO}_{4}, \mathrm{pH}$. In some samples GvpC was removed by rinsing $50 \mu$ l of concentrated gas vesicles three times through saturated urea $(\sim 10 \mathrm{M})$; the urea was then removed by dialysis against deionized water. The gas vesicle samples were then further concentrated to $100 \mu \mathrm{g} \mathrm{ml}^{-1}$ by centrifugal flotation and treated with Ziptip (Millipore) before MALDI-TOF analysis. For pressure nephelometry, $10 \mu \mathrm{l}$ samples of the gas vesicle digests were diluted in $3 \cdot 4 \mathrm{ml}$ of the same $\mathrm{pH} 8$ buffer (see below).

Similar digests were made using Staphylococcus V8 protease. Samples of concentrated gas vesicles $(30 \mu \mathrm{l})$ were diluted in $70 \mu \mathrm{l} \mathrm{pH} \mathrm{7.5}$ buffer containing $50 \mathrm{mM} \mathrm{NaH}_{2} \mathrm{PO}_{4}$ and $1 \mathrm{mM} \mathrm{Na}_{2}$ EDTA. V8 protease $(50 \mu \mathrm{g})$ was added and the sample mixed. The mixture was incubated at room temperature for $1 \mathrm{~h}$ or $16 \mathrm{~h}$. Samples were then rinsed three times by centrifugal flotation through $50 \mathrm{mM} \mathrm{NaH}_{2} \mathrm{PO}_{4}$ and $1 \mathrm{mM}$ $\mathrm{Na}_{2}$ EDTA, pH $7 \cdot 5$, and prepared for MALDI-TOF analysis.

MALDI-TOF MS. We analysed the molar masses of proteins and peptides by MALDI-TOF MS with a PE Biosystems Voyager-DE STR Maldi-Tof mass spectrometer, using a nitrogen laser operating at $337 \mathrm{~nm}$. The peptides were analysed in positive ion reflector mode, for masses below $10 \mathrm{kDa}$, using $\alpha$-cyano-4-hydroxycinnamic acid matrix. Each monoisotopic mass $\left(M_{\mathrm{i}}\right)$ was recorded with an accuracy of $50-100$ p.p.m. Above $10 \mathrm{kDa}$, peptides were analysed in linear mode using sinapinic acid as a matrix. Mean masses were recorded with an accuracy of $0 \cdot 1 \%$.

Pressure nephelometry. The critical pressure distribution of gas vesicles was measured by pressure nephelometry (Walsby, 1973). Measurements (in triplicate) were made on isolated gas vesicles suspended in $5 \mathrm{mM} \mathrm{NaCN}$ and $10 \mathrm{mM} \mathrm{K}_{2} \mathrm{HPO}_{4}$ (Walsby \& Bleything 1988), pH 8, which is optimum for their stability (Buckland \& Walsby, 1971). Measurements were made on isolated gas vesicles treated as follows: untreated gas vesicles; gas vesicles incubated in trypsin $\left(4 \mathrm{mg} \mathrm{ml}^{-1}\right)$ to cleave, but not remove, the outer GvpC; gas vesicles stripped of the outer protein GvpC by rinsing in saturated $(\sim 10 \mathrm{M})$ urea; gas vesicles treated with urea to remove GvpC and then incubated in trypsin to cut the N-terminal AVEK-peptide from GvpA. The effects of different incubation times in trypsin, from $5 \mathrm{~min}$ up to $24 \mathrm{~h}$, were investigated.

\section{RESULTS}

We identified proteins and peptides present before and after removal of GvpC, and before and after exposure to trypsin 
and V8 protease. The numbers given in the text below and in Table 1 are means of two or three measurements.

\section{Gas vesicles stripped of GvpC}

In the first analysis of isolated gas vesicles treated with $10 \mathrm{M}$ urea to remove GvpC, we obtained a single prominent peak with $m / z=7403$, where $m / z$ is $\left(M_{\mathrm{i}}+\mathrm{H}\right)^{+} /$charge, compared with an expected $M_{\mathrm{i}}$ of 7393 for GvpA, an error of $0.12 \%$ in linear mode. The mean \pm SD of nine spectra observed was $7393 \pm 10$.

\section{Gas vesicles stripped of GvpC, trypsin digest}

In urea-treated samples digested with trypsin a second peak appeared, of $m / z=6962$. This was identified as GvpA minus the N-terminal tetrapeptide, of sequence AVEK, which has an expected value of 6966. This confirms the finding of Belenky et al. (2004) that the tetrapeptide was accessible at the outer surface of the gas vesicle; P. K. Hayes also demonstrated that trypsin cleaved off some of the $\mathrm{N}$ terminal tetrapeptide by isolating and sequencing the peptide (unpublished results).

There was one occurrence (out of three runs), in a trypsindigested sample not treated with urea, of an additional fragment of $m / z=1378$ (Fig. 1a). This corresponds with the sub-N-terminal tryptic peptide of GvpA, TNSSSSLAEVIDR; it suggests that both ends of this sequence are present at the outer surface of the gas vesicle but, unlike the N-terminal AVEK, this tryptic peptide was not released. The identity of this fragment needs confirmation, however, because we did

Table 1. $M_{\mathrm{i}}$ values of tryptic peptides of $A$. flos-aquae GvpC compared with those of peptides obtained by digestion of gas vesicles: (a) peptides remaining attached to intact gas vesicles; (b) peptides released from them

The numbers given (except those in brackets) are means of two or three measurements.

\begin{tabular}{|c|c|c|c|c|c|c|}
\hline \multirow[t]{2}{*}{ Peptide } & \multirow[t]{2}{*}{ Amino acid sequence } & \multicolumn{4}{|c|}{ Monoisotopic mass $[(\mathrm{m} / z)-1]^{*}$} & \multirow[t]{2}{*}{ Notes $\dagger$} \\
\hline & & $\begin{array}{l}\text { Total, from } \\
\text { sequence }\end{array}$ & $\begin{array}{l}\text { (a) Trypsin, } \\
\text { attached }\end{array}$ & $\begin{array}{l}\text { (b) Trypsin, } \\
\text { released }\end{array}$ & $\begin{array}{l}\text { Untreated gas } \\
\text { vesicles }\end{array}$ & \\
\hline $\mathrm{T} 1$ & MISLMAK & $792 \cdot 4[824 \cdot 4]$ & $824 \cdot 6$ & $824 \cdot 6$ & - & $1,2,5$ \\
\hline $\mathrm{T} 2$ & IR & $287 \cdot 2$ & - & $287 \cdot 9$ & - & 2 \\
\hline T3 & QEHQSIAEK & $1068 \cdot 5$ & - & - & - & 3 \\
\hline $\mathrm{T} 4$ & VAELSLETR & $1016 \cdot 6$ & $1016 \cdot 5$ & $1016 \cdot 6$ & - & \\
\hline T5 & EFLSVTTAK & $994 \cdot 5$ & - & - & - & \\
\hline T6 & $\mathrm{R}$ & $174 \cdot 1$ & - & - & - & 2,4 \\
\hline T7 & QEQAEK & $731 \cdot 3$ & - & $(727 \cdot 8)$ & - & $2,3,6$ \\
\hline $\mathrm{T} 6+\mathrm{T} 7$ & RQEQAEK & $887 \cdot 5$ & - & $887 \cdot 3$ & - & 2 \\
\hline T8 & QAQELQAFYK & $1224 \cdot 6$ & $1224 \cdot 6$ & $1224 \cdot 4$ & - & 3 \\
\hline T12 & ELQETSQQFLSATAQAR & $1906 \cdot 9$ & $1907 \cdot 8$ & $1907 \cdot 8$ & - & \\
\hline T13 & IAQAEK & $658 \cdot 4$ & - & $(658 \cdot 3)$ & - & 2,5 \\
\hline T14 & QAQELLAFYQEVR & $1593 \cdot 8$ & $1593 \cdot 7$ & $1593 \cdot 7$ & - & 3 \\
\hline T15 & ETSQQFLSATAQAR & $1536 \cdot 8$ & $1536 \cdot 7$ & $1536 \cdot 6$ & - & \\
\hline T16 & IAQAEK & $658 \cdot 4$ & - & $(658 \cdot 3)$ & - & 2,5 \\
\hline T17 & QAQELLAFHK & $1183 \cdot 6$ & $1183 \cdot 6$ & $1183 \cdot 8$ & - & 3 \\
\hline T18 & ELQETSQQFLSATADAR & $1893 \cdot 9$ & $1893 \cdot 8$ & $1894 \cdot 0$ & - & \\
\hline T19 & TAQAK & $517 \cdot 3$ & - & - & - & 2 \\
\hline T20 & EQK & $403 \cdot 2$ & $(403 \cdot 2)$ & - & - & 2 \\
\hline T21 & ESLLK & $588 \cdot 4$ & - & - & - & 2 \\
\hline T22 & FR & $321 \cdot 2$ & - & - & - & 2 \\
\hline
\end{tabular}

${ }^{*}$ Values in parentheses indicate a weak signal present in only one analysis.

$\dagger 1$, Two M residues may oxidize [oxidized mass]. 2, Small molecules: signals may be obscured by background of matrix. 3, If N-terminal Q is deaminated to E, mass increases by 1. 4, Single R residue, unlikely to be found. 5, Hydrophobic peptide, may not dissolve. 6, Poor mass agreement. 


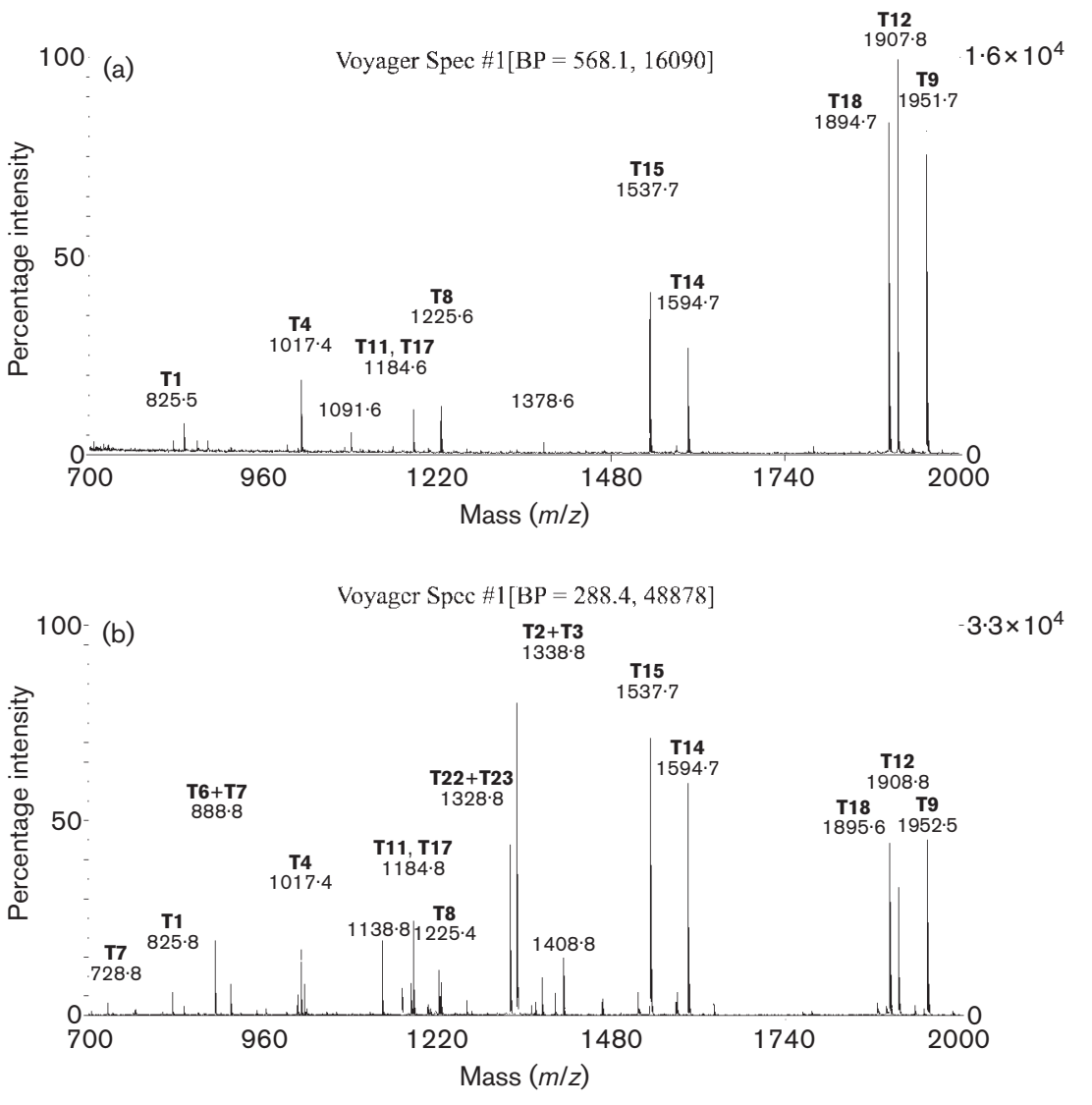

Fig. 1. Mass spectra of $A$. flos-aquae gas vesicles digested with trypsin: (a) attached GvpC tryptic peptides; (b) detached GvpC tryptic peptides. Mass sizes given are monoisotopic mass $\left(M_{\mathrm{i}}\right)$, after deisotoping. not find it in a urea-treated sample and we did not find the fragment of $m / z=5606 \cdot 2$, representing GvpA minus the first two tryptic fragments.

\section{Entire gas vesicles, containing GvpC}

Further investigations were confined to gas vesicles carrying the outer protein, GvpC, whose presence was confirmed by bands of $\sim 22000 \mathrm{Da}$ in PAGE (Walsby \& Hayes, 1988). In a MALDI-TOF MS spectrum over the mass range $1-4 \times 10^{4}$, of gas vesicles containing GvpC, the most prominent peak was at $m / z=21961$ (within $0.05 \%$ of the expected $M_{\mathrm{i}}$ for GvpC of 21972). The only other prominent peaks were at 11042 (the doubly charged version of GvpC) and at 14823 , which corresponded with a dimer of GvpA (expected value $14786)$.

\section{Entire gas vesicles containing GvpC, digested with trypsin}

It was expected that after treatment with trypsin the GvpC would be cut at all post- $\mathrm{R}$ and $-\mathrm{K}$ sites available to the enzyme: those tryptic peptides with sites that bind them to GvpA would remain on the gas vesicles while those lacking binding sites would be released into the digest. Following digestion, the mixture was centrifuged and the floating gas vesicles were separated from the subnatant suspension. The floating gas vesicles were rinsed twice more to remove unbound peptides. Samples of both the rinsed gas vesicles and the first subnatant were analysed by MALDI-TOF MS. Table 1 list all the possible tryptic peptides (those terminating in $\mathrm{K}$ or $\mathrm{R}$ ) and the three cases of adjacent pairs of tryptic peptides where the $\mathrm{N}$-terminal peptide constituted only one or two amino acids.

Attached GvpC tryptic peptides. Analysis of the rinsed trypsinized gas vesicles indicated a number of products, most of which were clearly identifiable with tryptic peptides of GvpC (Fig. 1a). Those identified were all within $1 \mathrm{Da}$ of the expected $M_{\mathrm{i}}$. Many of the tryptic peptides retained on the gas vesicles were from the region T4 to T18 on GvpC. Fig. 2 indicates the disposition of the attached tryptic products in relation to the amino acid sequence of the GvpC molecule and the location of the $33 R R$ s.

Of these attached peptides, the strongest signals were given by the three longest (T9, T12 and T18, each of 17 residues) and the next strongest by the next longest (T15 of 14 residues and T14 of 13 residues). Those peptides considered missing from this middle section were among the shortest, including the single $\mathrm{R}$ residue (T6) and four hexapeptides (T7, and the identical T10/T13/T16). There was a small signal at $m / z=825 \cdot 6$, which corresponds to $\mathrm{T} 1$, the N-terminal peptide, in which both $\mathrm{M}$ residues are oxidized. There were no consistent traces of the next two peptides (T2, T3). The 
MISLMAKIRQEHQSIAEK Repeat

VAELSLETR $E$ FSVTTAKRQEQAEKQAQELQAF

1

YKDLQETSQQFLSETAQARIAQAEKQAQELLAF

HKELQETSQQFLSATAQARIAQAEKQAQELLAF

YQEVRETSQQFLSATAQAR IAQAEKQAQELLAF

HKELQETSQQFLSATADARTAQAKEQREESLLKEF

2

3

4

5

RQDLFVSIFG

Fig. 2. Amino acid sequence of $A$. flos-aquae $\mathrm{GvpC}$ showing the five $33 R R$ s. The underlined $\mathrm{K}$ and $\mathrm{R}$ residues indicate positions where trypsin cut the protein. Tryptic peptides that remained attached to the gas vesicle are in shown in bold.

last five tryptic peptides at the C-terminal end (T19-T23) were absent in two of three analyses made but in a third analysis there was a trace of the small T20. Most of the missing peptides at the two ends are short, though $\mathrm{T} 3$ and T23 are nonapeptides, of the same length as T4, which did remain attached. The footnotes to Table 1 give reasons why specific peptides might have been missed in the analysis owing to insolubility or lack of charge.

We also performed analyses on gas vesicles incubated for just $1 \mathrm{~h}$ in trypsin; the results were largely similar but small signals indicated that small proportions of two of the peptide pairs, $\mathrm{T} 2+\mathrm{T} 3$ and $\mathrm{T} 22+\mathrm{T} 23$, remained attached to the gas vesicles.

Detached GvpC tryptic peptides. A similar analysis was made on the first subnatant, containing peptides released from the trypsinized gas vesicles (Fig. 1b; Table 1). The list contains many of the same peptides that were attached to the gas vesicles, indicating that for those, the binding was not firm enough to prevent partial removal. The main differences between the subnatant and gas vesicle samples were in the presence of the three peptide pairs. The largest signal was given by the $\mathrm{T} 2+\mathrm{T} 3$ peptide pair. Strong signals were also given by $\mathrm{T} 6+\mathrm{T} 7$ and by $\mathrm{T} 22+\mathrm{T} 23$ at the $\mathrm{C}$-terminus. These three peptide pairs were absent from the fully trypsinized gas vesicles. A weak peak corresponding to T10/13/16 was found in one of two digests; its identity is uncertain because it matches the mass of a trypsin autolysis fragment. There were several small peaks which could not be identified with any of the expected tryptic products (see below). The largest of these, with $m / z=1138 \cdot 4$ and $1408 \cdot 4$, were about the same size as the smallest identifiable peak, peptide 8 with $m / z=1224 \cdot 4$.

\section{Products of other gvp genes}

If the products of other $g v p$ genes form part of the gas vesicle structure, it should be possible to recover them from isolated gas vesicles. Some of the possible products might be present in very small quantities (one molecule per rib or per end) and detectability would depend on the sensitivity of the technique used.

We drew up lists of the $M_{\mathrm{i}}$ values of the other seven Gvps (GvpN, J, K, F, G, V, W) of A. flos-aquae to see of any of them were present among the products of MALDI-TOF MS analysis of isolated gas vesicles. None of them were found.

We also listed the $M_{\mathrm{i}}$ values of all the possible tryptic peptides, including adjacent pairs of tryptic products, in these nine Gvp proteins. Apart from the various tryptic products of GvpA and GvpC described above, the only other identifiable peak was a peak of $m / z=2163$, which was either an autolysis product of trypsin itself $(2163 \cdot 3)$ or the fourth tryptic fragment of GvpJ (2163.2). The latter seems unlikely because there was no signal for the entire GvpJ molecule. No other identifiable fragments were found.

\section{Staphylococcus V8 protease digest}

For the $16 \mathrm{~h}$ digest with V8 protease the MALDI-TOF spectrum for mass 500-2000 contained no substantial peaks. A few peaks were present in the spectrum of the $1 \mathrm{~h}$ digest but none of them corresponded in size with the peptides that would be generated by cleavage at the $\mathrm{D}$ and $\mathrm{E}$ residues in GvpC.

\section{Changes in critical pressure of gas vesicles}

The effects on gas vesicle strength of removing and/or cleaving gas vesicle proteins were investigated by measuring the critical pressure distributions. Buckland \& Walsby (1971) showed that gas vesicles of A. flos-aquae were markedly weakened by pronase, an unspecific protease that may have digested both GvpC and GvpA.

The untreated gas vesicles isolated from A. flos-aquae had a mean critical pressure of $0.63 \pm 0.002 \mathrm{MPa}$ (Fig. 3). In all of the following treatments (urea, trypsin digestion), the suspension retained its milky appearance before pressure, indicating that the gas vesicles remained with their gas spaces intact. After gas vesicles had been stripped of GvpC with concentrated urea, the mean critical pressure fell to $0 \cdot 21 \pm 0 \cdot 001 \mathrm{MPa}$, as observed in previous investigations (Hayes et al., 1992; Buchholz et al., 1993). Isolated gas vesicles were also weakened, though less so, by exposure to trypsin for $1 \mathrm{~h}$, which partially digests GvpC: the mean critical pressure decreased to $0 \cdot 37 \pm 0 \cdot 001 \mathrm{MPa}$. When these trypsinized gas vesicles were subsequently treated with concentrated urea, however, the gas vesicles were further weakened, to $0 \cdot 20 \pm 0 \cdot 001 \mathrm{MPa}$, similar to the result with the stripped gas vesicles. When the order of these treatments was reversed, i.e. the gas vesicles were first stripped of GvpC and the remaining GvpA shell then exposed to trypsin, the same result was obtained, a critical pressure of $0 \cdot 20 \pm 0 \cdot 004 \mathrm{MPa}$. Evidently, the cleaving of the N-terminal sequence AVEK- did not further weaken the structure. 


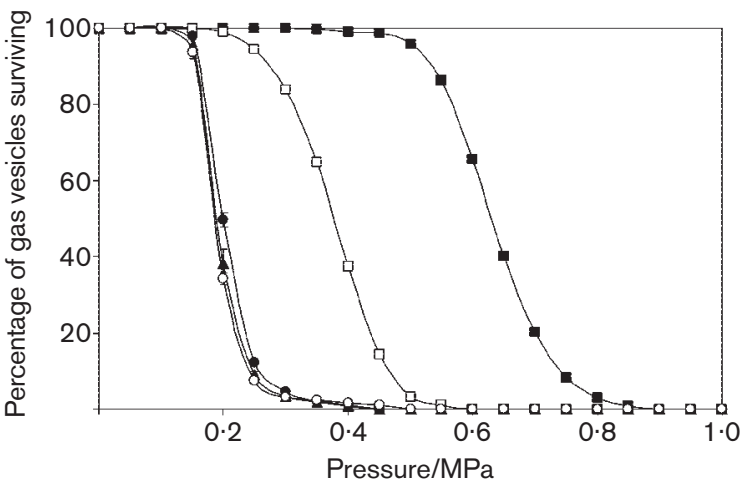

Fig. 3. Critical pressure distributions of isolated gas vesicles: $\boldsymbol{\square}$, entire gas vesicles; $\square$, exposed to trypsin for $1 \mathrm{~h}$, to cleave but not remove GvpC; $\bullet$, stripped of GvpC by $10 \mathrm{M}$ urea; $\bigcirc$, digested with trypsin and then stripped of the tryptic peptides; $\boldsymbol{\Delta}$, stripped of GvpC and then digested with trypsin to cleave the N-terminal peptide from GvpA.

The effects of different exposure times to trypsin are shown in Fig. 4. After complete digestion $(24 \mathrm{~h})$ the critical pressure had fallen to $0 \cdot 20 \mathrm{MPa}$, the same value obtained after removal of the intact or partial tryptic fragments. The time-course indicated that significant changes had occurred after only $5 \mathrm{~min}$ exposure to trypsin (critical pressure $0 \cdot 47 \mathrm{MPa}$ ). Complete digestion required digestion for over $5 \mathrm{~h}$ (critical pressure $0 \cdot 23 \mathrm{MPa}$ after $5 \cdot 2 \mathrm{~h}$ ).

\section{DISCUSSION}

The results in Table 1 provide information on which parts of the attached GvpC molecule are available for cleavage by trypsin. They also indicate which parts of the cleaved GvpC remain attached to the gas vesicle and which parts are released.

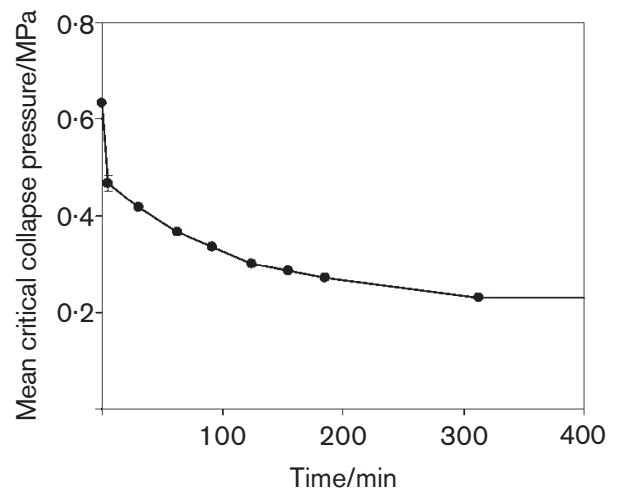

Fig. 4. Mean critical pressures of isolated gas vesicles exposed to trypsin for different times. Error bars indicate 95\% confidence limits (most are smaller than the symbols).

\section{Orientation of GvpC: sites available for cleavage}

We first consider the evidence on which tryptic sites on GvpC are available for cleavage by the enzyme, with the idea that this might distinguish those facing out from those facing in towards the gas-vesicle surface, which might be inaccessible to the enzyme.

The list of tryptic peptides found indicates that, although not all of the possible products were obtained, nearly all the tryptic sites were cleaved. For example, while peptide T3 was not obtained, the flanking peptides T2 and T4 were, indicating cleavage at both ends of $\mathrm{T} 3$; the occurrence of the peptide pair T2 + T3 confirms cleavage at the end of T3. There is some doubt about whether trypsin cleaves after both the adjacent $\mathrm{K}$ and $\mathrm{R}$ residues at the end of peptides $\mathrm{T} 5$ and $\mathrm{T} 6$, because $\mathrm{T} 5$ was not obtained, $\mathrm{T} 6$ is indistinguishable from signals given by the matrix and the evidence for T7 is uncertain (present in only one sample, poor mass agreement); however, the peptide pair T6 + T7 confirms that a cut occurs after the $\mathrm{K}$ residue at the end of T5. There is strong evidence for cleavage of all the next tryptic sites up to T18; a candidate peak for T20 in one sample extends this to the end of T20. The strong signal for the peptide pair T22+T23 indicates that the site at the end of T21 was cut even though T21 was not obtained but it is uncertain if a cut occurs after the $\mathrm{R}$ at the end of $\mathrm{T} 22$, as the evidence for a separate $\mathrm{T} 23$ is poor.

These results suggest that, at the most, only two of the tryptic sites (post-T6 and -T22) are inaccessible to the enzyme. It is not possible that all $\mathrm{K}$ and $\mathrm{R}$ residues are arranged facing outwards on a continuous $\alpha$-helix because there are examples of $\mathrm{R} / \mathrm{K}$ residues at intervals of two, three, five and six residues, which must face in different directions. The results suggest that trypsin is able to reach residues at all points on the open helix as the protein vibrates dynamically on the gas vesicle surface. It is therefore not possible to obtain information on the orientation by trypsin digestion. Speculations on structure are made below, but for evidence, crystallographic studies are needed.

\section{Regions of GvpC that bind or do not bind to GvpA}

The second purpose of these experiments was to determine which parts of the GvpC were bound to the underlying GvpA gas vesicle by determining which tryptic peptides remained attached to the gas vesicle and which were rinsed off from it. In summary, the results indicated that there are few tryptic peptides that do not bind to some degree, but of the many that do, none bind as strongly as the entire, undigested $\mathrm{GvpC}$, which remains strongly attached in water. It is difficult to determine the ratios of bound to unbound peptide, or the ratios of different peptides, because several factors - e.g. the peptide's size, charge and solubility - affect the signal strength, but we comment on the major differences. For a few of the peptides no signal was detected, 
either because cleavage was incomplete or because the peptide did not fly in the mass spectrometer. The evidence on binding of the different tryptic peptides is considered.

The tryptic peptide $\mathrm{T} 1$ was not initially recognized: oxidation of the two $M$ residues increases its mass from $792 \cdot 4$ (no corresponding signal) to $824 \cdot 6$. Small signals with this mass were found in samples of both the floating gas vesicles and the subnatant rinsing.

The peptide pair $\mathrm{T} 2+\mathrm{T} 3$ is evidently from a region that does not bind because it occurs exclusively in the subnatant, where it gave the strongest signal (Fig. 1b). The single T2 peptide occurred only in the subnatant: this dipeptide, once cleaved off, would be too small to remain bound, but the fact that it forms part of a larger peptide pair that does not bind suggests that in the intact protein it does not form part of a binding site.

The first of the five 33RRs shows lower homology to the $33 R R$ consensus sequence than the rest but nevertheless resembles them in the pattern of binding. The first part, T4, occurred in both the bound and subnatant fractions. There was no evidence for $\mathrm{T} 5$, which was missing in both fractions. The exclusive presence of the peptide pair $\mathrm{T} 6+\mathrm{T} 7$ in the subnatant suggests that this region of GvpC does not bind.

There are three conserved classes of tryptic peptides in the $33 R R s$, of which two remain attached to the gas vesicle. The first class comprises the four products T8, T11, T14 and T17 containing the sequence QAQELXAF (Fig. 2), which all give strong signals in the gas vesicle fraction and somewhat smaller signals in the subnatant. The second class comprises the adjacent four products T9, T12, T15 and T18 containing the sequence ETSQQFLSXTAXAR (Fig. 2), which give the strongest signals in the gas vesicle fraction and smaller signals in the subnatant. Together, these two classes constitute a continuous run of 27 of the 33 residues that binds to the gas vesicle, perhaps at these conserved sequences.

It was previously suggested that each of the five $33 R R \mathrm{~s}$ in the Anabaena GvpC molecule would interact in the same way with an underlying repeating structure on GvpA at the gas vesicle surface: binding might occur either at the $33 R R$ s or at the peripheral $\mathrm{N}$ - and $\mathrm{C}$-terminal sequences, with the 33RRs acting as spacers (Buchholz et al., 1993; Kinsman et al., 1995). This investigation shows that regions within the $33 R R s$ bind to GvpA and therefore the 33RRs are not simply unbound spacers.

Each of the 33RRs contains a third class of tryptic peptide, which includes the T6 $+\mathrm{T} 7$ peptide pair containing the sequence QAEK, the three identical peptides T10, T13, T16 of sequence IAQAEK, and T19 containing AQA (Fig. 2). No trace of any of these was found in the gas vesicle faction but some of them appeared in the subnatant: $\mathrm{T} 6+\mathrm{T} 7$ was in all samples; a weak peak of mass $658 \cdot 3$, which corresponds to either T10/13/16 or a trypsin autolysis fragment, occurred in some samples; T19 was absent from all of them. It is concluded that these peptides are from regions that do not bind as strongly to the gas vesicle.

There is little evidence of bound or released peptides from the region covered by peptides T19 to T21 but the peptide pair T22 + T23 from the C-terminal end of GvpC provides the strongest signal in the subnatant and indicates that this region of GvpC is not strongly bound to the gas vesicle. Kinsman et al. (1995) found that recombinant Anabaena GvpC lacking the last 10 residues did not bind to stripped gas vesicles whereas the protein containing the sequence did bind. Perhaps the $\mathrm{C}$-terminal region is required to locate the protein correctly but once attached does not play much part in its binding.

\section{Speculations on binding of GvpC to GvpA}

Three types of interactions might link the two proteins - ion pairs, hydrophobic interactions and hydrogen bonds. Ion pairs form between positively charged residues $(\mathrm{H}, \mathrm{K}, \mathrm{R})$ and negatively charged ones (D, E); they may be of minor importance in binding GvpC because salt solutions, which compete for these charges, affect gas vesicle stability only at high concentrations (Buckland \& Walsby, 1971). Hydrophobic interactions occur predominantly between the less water-soluble residues: A, V, L, I and F in GvpC (P, C and W are absent from $\mathrm{GvpC}$ and $\mathrm{M}$ is absent from the $33 R R \mathrm{~s})$. Hydrogen bonds require a donor $(\mathrm{K}, \mathrm{R}, \mathrm{H})$ and an acceptor (D, E); Q, N, S and T can act as both simultaneously. Q is the best hydrogen-bonding candidate, providing the amide on a longer side chain. (The listing of the tryptic peptides in Table 1 draws attention to a previously unnoticed feature of the GvpC amino acid sequence: with the sole exception of peptide $\mathrm{T} 15$, in every tryptic peptide within the $33 R R \mathrm{~s}$, the third residue after each $\mathrm{K} / \mathrm{R}$ is a Q.) Concentrated urea, which removes GvpC from the gas vesicle (Hayes et al., 1992), can weaken all three types of interaction: the two amino groups of urea form ion pairs with carboxyls on acid residues; urea weakens hydrophobic interactions by chaotropic interference; and urea provides competing sites for hydrogen bonds.

Whatever the type of interaction, those residues that bind $\mathrm{GvpC}$ to the gas vesicle must be located adjacent to GvpA. If the chain of $33 R R$ s is in the form of a continuous $\alpha$-helical rod (which requires confirmation), the equivalent interactions in each successive $33 R R$ must occur on the same side of the helix. The angular distribution of residues along the $\alpha$-helical 33RRs of Anabaena GvpC is analysed using a polar plot of the 33 residues in the consensus sequence (Fig. 5), arranged at an angle between residues of $98 \cdot 2^{\circ}$ (see below). Of those able to form ionic bonds, the positively charged $\mathrm{K}$, $\mathrm{K}$ and $\mathrm{R}$ residues are distributed in different sectors but the four negatively charged $\mathrm{E}$ residues are all on one side of the helix (the upper half in Fig. 5). Calculations based on amino acid composition indicate that GvpA has an acidic isoelectric point and is negatively charged at cellular $\mathrm{pH}$ values. The hydrophobicity of the interior surface of GvpA suggests that the residual negative charge is located at the 


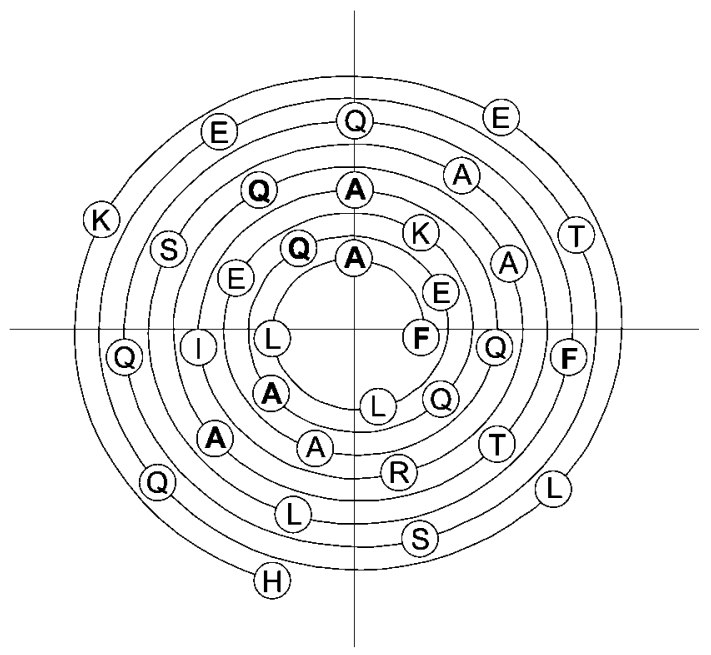

Fig. 5. Polar plot of the 33 amino acid residues in the conserved sequence of $33 R R$ s in A. flos-aquae GvpC. Conserved 11-residue repeats are indicated in bold.

outer surface, where it would repel the negatively charged (upper) side of GvpC. All of the most hydrophobic residues $(\mathrm{V}, \mathrm{L}, \mathrm{I}$ and $\mathrm{F})$ are on the other side (the lower half of the polar plot in Fig. 5), an arrangement that would allow hydrophobic interactions with GvpA. On that same (lower) side are four $\mathrm{Q}$ residues, an $\mathrm{S}$, a $\mathrm{T}$ and an $\mathrm{R}$, which might form hydrogen bonds with residues on GvpA. All of this is speculative: the trypsin cleavage experiments have provided no information on the orientation of the helix; in fact concerning the arrangement portrayed in Fig. 5, the evidence is that the only tryptic site in the lower half (the gas-vesicle side) is not protected as it is strongly cleaved to produce the most abundant products, peptides T9, T12, T15 and T18 (but perhaps not T6).

\section{Speculation on the origin of 11RRs and 33RRs.}

In $\alpha$-helices, the angle between adjacent residues is commonly about $100^{\circ}$, though the exact angle depends on the identity of the component residues and other factors that may twist the helix. After 33 residues at $100^{\circ}$, a helix would turn through $9 \cdot 17$ gyres, giving a rotation of $60^{\circ}$ between the first and 34th (Buchholz et al., 1993). To bring successive $33 R R$ s into register requires a mean angle of $98 \cdot 2^{\circ}$ : this would result in nine complete gyres after 33 residues and three gyres after 11 residues. The vestigial $33 \mathrm{bp}$ repeat in gvpC (Damerval et al., 1987) indicates an ancestral protein with $11 R R$ s that would have provided identical binding sites every three gyres. Although the amino acid homology over intervals of 11 residues is now largely lost, there are four positions where it remains (Fig. 5).

One factor that might contribute to the twisting of the $\alpha$-helix is that it lies not on a planar surface but on the curved surface of the gas vesicle, which would bend the helix and perhaps tighten the spring. The degree of curvature will be less if the GvpC crosses the ribs at the proposed angle of $24^{\circ}$ (Walsby 1994) rather than lying along the ribs.

\section{Importance of integrity of GvpC in strengthening the gas vesicle}

The information obtained on the binding of GvpC fragments to gas vesicles aids the interpretation of effects of cleaving and/or removing GvpC on the strength of gas vesicles. As shown previously, complete removal of GvpC causes a nearly threefold decrease in critical pressure. Buchholz et al. (1993) showed that when the full-length GvpC was reassembled on the stripped gas vesicle the critical pressure was almost completely restored; Kinsman et al. (1995) showed that when recombinant GvpCs with only four, three or two $33 R R$ s were assembled on the stripped gas vesicles, progressively lower critical pressures resulted. The information that digestion with trypsin gradually decreases critical pressure suggests that as the tryptic peptides get shorter they provide less support until, with complete digestion, the remaining peptides provide no strengthening of the ribbed structure. In the context of the model that has GvpC binding across bands of five ribs (Buchholz et al., 1993), the remaining tryptic fragments may not be long enough to bind adjacent ribs together. Further experiments in which individual specific peptides are allowed to bind to the gas vesicle might reveal those that are most effective in postponing the buckling and collapse of the structure.

\section{ACKNOWLEDGEMENTS}

We thank Paul Hayes for advice and unpublished data on tryptic peptides of Gvps, and Ted Atkins and Richard Sessions for discussions on protein bonding. We are very grateful to Judith Herzfeld for many helpful suggestions on the manuscript. This work was supported by a BBSRC studentship to P. G. D. and a grant from the NERC.

\section{REFERENCES}

Belenky, M., Myers, R. \& Herzfeld, J. (2004). Subunit structure of gas vesicles: a MALDI-TOF MS study. Biophys J 86, 499-505.

Blaurock, A. E. \& Walsby, A. E. (1976). Crystalline structure of the gas vesicle wall from Anabaena flos-aquae. J Mol Biol 105, 183-199.

Blaurock, A. E. \& Wober, W. (1976). Structure of the wall of Halobacterium halobium gas vesicles. J Mol Biol 106, 871-888.

Booker, M. J. \& Walsby, A. E. (1979). The relative form resistance of straight and helical blue-green algal filaments. Br Phycol J 14, 141-150.

Buchholz, B. E. E., Hayes, P. K. \& Walsby, A. E. (1993). The distribution of the outer gas vesicle protein, GvpC, on the Anabaena gas vesicle, and its ratio to GvpA. J Gen Microbiol 139, 2353-2363.

Buckland, B. \& Walsby, A. E. (1971). A study of the strength and stability of gas vesicles isolated from a blue-green alga. Arch Microbiol 79, 327-337.

Damerval, T., Houmard, J., Guglielmi, G., Csiszàr, K. \& Tandeau De Marsac, N. (1987). A developmentally regulated gvpABC operon 
is involved in the formation of gas vesicles in the cyanobacterium Calothrix 7601. Gene 54, 83-97.

Dunton, P. \& Walsby, A. E. (2005). The diameter and critical collapse pressure of gas vesicles in Microcystis are correlated with GvpCs of different length. FEMS Lett 247, 37-43.

Hayes, P. K., Walsby, A. E. \& Walker, J. E. (1986). Complete amino acid sequence of cyanobacterial gas-vesicle protein indicates a 70 residue molecule that corresponds in size to the crystallographic unit cell. Biochem J 236, 31-36.

Hayes, P. K., Lazarus, C. M., Bees, A., Walker, J. E. \& Walsby, A. E. (1988). The protein encoded by $g v p C$ is a minor component of gas vesicles isolated from the cyanobacteria Anabaena flos-aquae and Microcystis sp. Mol Microbiol 2, 545-552.

Hayes, P. K., Buchholz, B. \& Walsby, A. E. (1992). Gas vesicles are strengthened by the outer-surface protein, GvpC. Arch Microbiol 157, 229-234.

Horne, M., Englert, C., Wimmer, C. \& Pfeifer, F. (1991). A DNA region of $9 \mathrm{kbp}$ contains all genes necessary for gas vesicle synthesis in halophilic archaebacteria. Mol Microbiol 5, 1159-1174.

Jones, D. D. \& Jost, M. (1970). Isolation and chemical characterization of gas vacuole membranes from Microcystis aeruginosa Kuetz. emend. Elenkin. Arch Microbiol 70, 43-64.

Jones, D. D. \& Jost, M. (1971). Characterization of the protein from gas vacuole membranes of the blue-green algae Microcystis aeruginosa. Planta 100, 277-287.

Kinsman, R. \& Hayes, P. K. (1997). Genes encoding proteins homologous to the halobacterial Gvps N, J, K, F and L are located downstream of $g v p C$ in the cyanobacterium Anabaena flos-aquae. DNA Seq 7, 97-106.

Kinsman, R., Walsby, A. E. \& Hayes, P. K. (1995). GvpCs with reduced numbers of repeating sequence elements bind to and strengthen cyanobacterial gas vesicles. Mol Microbiol 17, 147-154.

McMaster, T. J., Miles, M. J. \& Walsby, A. E. (1996). Direct observation of protein secondary structure in gas vesicles by atomic force microscopy. Biophys J 70, 2432-2436.

Mlouka, A., Comte, K., Castets, A.-M., Bouchier, C. \& Tandeau de Marsac, N. (2004). The gas vesicle gene cluster from Microcystis aeruginosa and DNA rearrangements that lead to loss of cell buoyancy. J Bacteriol 186, 2355-2365.
Offner, S., Wanner, G. \& Pfeifer, F. (1996). Functional studies of the gvpACNO operon of Halobacterium salinarium reveal that the GvpC protein shapes gas vesicles. J Bacteriol 178, 2071-2078.

Offner, S., Ziese, U., Wanner, G., Typke, D. \& Pfeifer, F. (1998). Structural characteristics of halobacterial gas vesicles. Microbiology 144, 1331-1342.

Offner, S., Hofacker, A., Wanner, G. \& Pfeifer, F. (2000). Eight of fourteen $g v p$ genes are sufficient for formation of gas vesicles in halophilic archaea. J Bacteriol 182, 4328-4336.

Rost, B., Yachdav, G. \& Liu, J. (2004). The PredictProtein Server. Nucleic Acids Res 32, W321-W326.

Shukla, H. D. \& DasSarma, S. (2004). Complexity of gas vesicle biogenesis in Halobacterium sp. strain NRC-1: identification of five new proteins. J Bacteriol 186, 3182-3186.

Tandeau de Marsac, N., Mazel, D., Bryant, D. A. \& Houmard, J. (1985). Molecular cloning and nucleotide sequence of a developmentally regulated gene from the cyanobacterium Calothrix PCC 7601: a gas vesicle protein gene. Nucleic Acids Res 13, 7223-7236.

Walsby, A. E. (1969). The permeability of blue-green algal gasvacuole membranes to gas. Proc $R$ Soc Lond B 173, 235-255.

Walsby, A. E. (1973). A portable apparatus for measuring relative gas vacuolation, the strength of gas vacuoles, and turgor pressure in planktonic blue-green algae and bacteria. Limnol Oceanogr 18, 653-658.

Walsby, A. E. (1982). The elastic compressibility of gas vesicles. Proc $R$ Soc Lond B 216, 355-368.

Walsby, A. E. (1994). Gas vesicles. Microbiol Rev 58, 94-144.

Walsby, A. E. \& Bleything, A. (1988). The dimensions of cyanobacterial gas vesicles in relation to their efficiency in providing buoyancy and withstanding pressure. J Gen Microbiol 134, 2635-2645.

Walsby, A. E. \& Buckland, B. (1969). Isolation and purification of intact gas vesicles from a blue-green alga. Nature 224, 716-717.

Walsby, A. E. \& Hayes, P. K. (1988). The minor cyanobacterial gas vesicle protein, GVPc, is attached to the outer surface of the gas vesicle. J Gen Microbiol 134, 2647-2657.

Worcester, D. L. (1975). Neutron diffraction studies of biological membrane components. In Neutron Scattering for the Analysis of Biological Structures. Brookhaven Symp Biol 27, III-37-III-57. 